\title{
Evaluation of Role of Inflammatory Markers for the Prediction of Recurrence on Pathologic T1a Clear Cell Renal Cell Cancer Patients
}

\author{
Patolojik T1a Evreli Șeffaf Hücre Renal Hücreli Kanser Hastalarında Nüksü \\ Öngörmede Inflamasyon Belirteçlerinin Rolünün Değerlendirilmesi
}

\author{
Mehmet Illker Gökçe MD1, Nurullah Hamidi MD1, Barış Esen MD1, Semih Tangal MD2, Evren Süer MD1, Sümer Baltacı MD1 \\ ${ }^{1}$ Ankara University Faculty of Medicine, Department of Urology, Ankara, Turkey \\ 2Ufuk University Faculty of Medicine, Department of Urology, Ankara, Turkey
}

\begin{abstract}
Summary
Objective: To evaluate the role of neutrophil to lymphocyte ratio (NLR), high sensitive C-reactive protein (hs-CRP) and procalcitonin levels in the prediction of tumor recurrence in stage $\mathrm{T} 1 \mathrm{aNOMO}$ clear cell renal cell carcinoma (RCC).

Materials and Methods: We assessed 400 patients pathologically staged as T1aN0M0 clear cell RCC after radical or partial nephrectomy, in two institutions, between January 2007 and March 2014. Data of demographics, neutrophil and lymphocyte counts, NLR, hs-CRP, procalcitonin levels, tumor size, Fuhrmann nuclear grade and disease recurrence were collected. The primary outcome measure of this study was the evaluation of the relationship between NLR, hs-CRP and procalcitonin levels with recurrence free survival.

Results: The mean age and the mean tumor size of the patients were $56.8 \pm 13.1$ years and $29.3 \pm 7.7 \mathrm{~mm}$, respectively. Mean NLR, hs-CRP and procalcitonin levels were $3.2 \pm 2.6,0.822 \pm 0.404 \mathrm{mg} / \mathrm{L}$ and $0.088 \pm 0.05$ $\mathrm{ng} / \mathrm{mL}$, respectively. Fuhrmann Grade 1-2 and Fuhrmann Grade 3-4 tumor were observed in $76 \%$ and $24 \%$ of total patients, respectively. The mean follow up of the patient was 32.8 months. Totally tumor recurrence was detected in 5 patients. The receiver-operating characteristic analysis revealed cut off values of 4.50 for the NLR, $0.655 \mathrm{mg} / \mathrm{L}$ for hs-CRP and $0.078 \mathrm{ng} / \mathrm{mL}$ for and procalcitonin levels. In the multivariate analysis, the Fuhrmann grade $3-4(p=0.017)$ and NLR values $\geq 4.50(p=0.025)$ were detected to be associated with increased risk of recurrence.

Conclusions: High preoperative NLR value may be associated with increased risk of recurrence in stage pathologic T1a RCC patients. Studies with longer duration of follow up, prospective and larger populations are needed.
\end{abstract}

Keywords: Neutrophil-lymphocyte ratio, renal cell cancer, procalcitonin
Öz

Amaç: Evre T1aN0M0 şeffaf hücreli renal hücreli karsinom (RHK) hastalarında nüksü öngörmede Nötrofil/lenfosit oranı (NLO), yüksek duyarlııklı C-reaktif protein (yd-CRP) ve prokalsitonin düzeylerinin rolünün değerlendirilmesidir.

Gereç ve Yöntem: Ocak 2007-Mayıs 2014 tarihleri arasında, 2 merkezde, radikal ya da parsiyel nefrektomi sonrasında patolojik olarak T1aN0M0 olarak evrelendirilen 400 hasta değerlendirildi. Demografik bilgiler, nötrofil ve lenfosit sayıları, NLO, yd-CRP, prokalsitonin seviyeleri, tümör boyutu, Fuhrmann dereceleri ve hastalık nüksü ile ilgili bilgiler toplandı. Bu çalışmada birincil sonuç nükssüz sağkalım ile NLO, yd-CRP ve prokalsitonin düzeyleri arasındaki ilişkinin değerlendirilmesi idi.

Bulgular: Ortalama yaş ve ortalama sağ kalım sırası ile $56,8 \pm 13,1$ yıl ve $29,3 \pm 7,7 \mathrm{~mm}$ olarak bulundu. Ortalama NLO, yd-CRP ve prokalsitonin değerleri sırası ile $3,2 \pm 2,6 ; 0,822 \pm 0,404 \mathrm{mg} / \mathrm{L}$ ve $0,088 \pm 0,05 \mathrm{ng} / \mathrm{ml}$ olarak bulundu. Hastaların \%76'sında Fuhrmann derece 1-2, \%24'ünde ise Fuhrmann derece 3-4 tümör izlendi. Ortalama takip süresi 42,8 ay idi. Toplamda 5 hastada tümör nüksü saptandı. Alıcı işletim karakteristiğ analizi [Receiver operating characteristic (ROC)] ile NLO için 4,5, ydCRP için $0,655 \mathrm{mg} / \mathrm{L}$ ve prokalsitonin için 0,078 değerlerini eşik değer olarak bulundu. Çok değişkenli analizde, Fuhrmann derecenin 3-4 olması $(p=0,017)$ ve NLO'nun 4,5'in üzerinde olması $(p=0,025)$ artmış nüks riski ile ilişkili olduğu saptandı.

Sonuç: Evre T1 a RHK hastalarında operasyon öncesi yüksek NLO değerleri, artmış nüks riski ile ilişkili olabilir. Bu konuda daha uzun takip süresi ve daha geniş hasta sayısına sahip prospektif çalışmalara ihtiyaç vardır.

Anahtar Kelimeler: Nötrofil-lenfosit oranı, renal hücreli kanser, prokalsitonin 


\section{Introduction}

Renal cell carcinomas (RCC) present $2-3 \%$ of all cancers in adults and their annual incidence has increased in the last two decades, worldwide (1). The number of renal tumors diagnosed incidentally has increased recently due to the widespread use of non-invasive radiological imaging techniques for diagnosis of abdominal pathologies and this also leads to increased detection of smaller and lower stage renal tumors (2).

For the treatment of small renal masses, partial nephrectomy is currently accepted as the standard treatment. However, $20-30 \%$ of the localized RCC cases were shown to develop metastasis despite successful treatment. Therefore new clinical prognostic factors should be constituted in addition to already known prognostic factors like tumor $\mathrm{T}$ stage and tumor nuclear grade, which are not entirely reliable (3).

The association of systemic inflammation and carcinogenesis has been studied for many cancer types including RCC $(4,5,6,7,8)$. Neutrophil to lymphocyte ratio (NLR) has been studied as a marker of inflammation and its role in determination of prognosis of RCC has been verified recently $(8,9)$. Besides, high sensitive C-reactive protein (hs-CRP) and procalcitonin are the two other inflammatory markers associated with poorer prognosis in patients with RCC $(10,11,12,13)$. However in these studies, stage T1-4 RCC patients were involved and none of the existing studies focused on small renal masses of T1a stage.

In this study it was aimed to identify the role of NLR in the prediction of recurrence following radical or partial nephrectomy in stage T1aN0M0 clear cell RCC patients.

\section{Materials and Methods}

Patients underwent radical or partial nephrectomy for clear cell RCC in two clinics between January 2009 and March 2014 and stage pathologic T1aN0M0 disease, with at least 12 months of follow up were included in the study. Preoperative staging was performed by thoraco-abdominal CT and systematic lymph node dissection was done in case of radiologically detected lymphadenopathy or observed during surgery. Patients with pathologically positive lymph nodes were excluded from the study. Pathological examination revealed pathologic T stage, tumor grade and histological cell type. Tumors were staged according to the 2009 tumor, node, metastasis (TNM) criteria. Fuhrmann criteria are used for tumor grading (14).

\section{Exclusion Criteria}

Patients with a history of inflammatory disease that may modify the levels of inflammatory markers, clinical suspicion or laboratory signs of bacterial or viral infection, patients with history of chemotherapy, radiation therapy or any history of either, or use of anti-inflammatory drugs or systemic steroids were excluded from the study.

Data of the patients were collected from the medical records and included: age, gender, neutrophil and lymphocyte counts, NLR (NLR was calculated by dividing the absolute neutrophil count by the absolute lymphocyte count), hs-CRP measured (1-3 days before surgery), procalcitonin levels (measured 1-3 days before surgery), tumor size, Fuhrmann nuclear grade and disease recurrence. The primary outcome measure was the association of NLR, hs-CRP and procalcitonin levels with recurrence free survival. During the follow up all patients were evaluated with blood tests, chest x-ray at third month postoperatively and abdomen computerized tomography was performed at sixth month postoperatively and repeated at 6 months interval up to 2 years and continued annually thereafter.

\section{Statistical Analysis}

Normal distribution of the data was investigated by the Kolmogorov-Simirnov test and the data were expressed as the mean \pm standard deviation. Recurrence-free survival time was calculated from the date of nephrectomy to the date of radiological detection of recurrence. The cut off value for NLR, hs-CRP and procalcitonin levels for presence of recurrence was determined by receiver-operating characteristic (ROC) curve analysis. Further analysis was performed with dichotomous grouping of the population based on the cut off values determined from the ROC analysis. Survival curves were generated by the Kaplan-Meier method. Univariate survival analysis was performed with the log rank test. Multivariate analysis was performed using Cox regression analysis. For the statistical significance $p$ values $<0.05$ was accepted. All statistical analyses were performed with SPSS version 16.0 (Chicago, Illinois).

\section{Results}

Totally 400 patients met the eligibility criteria for analysis and involved in the study. The mean age of the patients was $56.8 \pm 13.1$ years. Two hundered sixty-eight patients (67\%) were males and 132 patients (33\%) were females. The mean tumor size was $29.3 \pm 7.7 \mathrm{~mm}$. The mean NLR, hs-CRP and procalcitonin levels were $3.2 \pm 2.6,0.822 \pm 0.404 \mathrm{mg} / \mathrm{L}$ and $0.088 \pm 0.05 \mathrm{ng} / \mathrm{mL}$, respectively. Fuhrmann Grade 1-2 tumor was observed in 304 patients (76\%) and Fuhrmann Grade 3-4 tumor was observed in 96 patients (24\%). Totally tumor recurrence was detected in 15 patients. The average duration of follow up of the population was 32.8 months.

The ROC analysis revealed cut off values of 4.50 (sensitivity $80.4 \%$, specificity $77.1 \%$ ), $0.655 \mathrm{mg} / \mathrm{L}$ (sensitivity $74.5 \%$, specificity $80.3 \%$ ) and $0.078 \mathrm{ng} / \mathrm{mL}$ (sensitivity $75.8 \%$, specificity $79.3 \%$ ) for the NLR, hs-CRP and procalcitonin levels, respectively.

The Kaplan-Meier analysis revealed that having tumor grade 3-4 $(p=0.001)$ and having NLR $\geq 4.50 \quad(p=0.001)$ were the only parameters associated with increased risk of recurrence. Kaplan-Meier curves are presented in Figure 1 and 2. Age, gender, tumor size, hs-CRP level and procalcitonin level were not found to be associated with increased risk of recurrence. The results of univariate analysis are summarized in Table 1. In the multivariate analysis, the tumor grade (HR: $2.547,95 \% \mathrm{Cl}$ : 1.455-6.023, $\mathrm{p}=0.017$ ) and NLR (HR: 1.883, 95\% Cl: $1.228-$ $3.177, p=0.025$ ) were again found to be associated with increased risk of recurrence.

\section{Discussion}

Systemic inflammation has a significant role in cancer development and progression (15). Markers of systemic inflammation have been studied in various cancer types including the RCC (4-8). CRP, procalcitonin and NLR are the commonly used markers of systemic inflammation. These markers are also shown to have correlation with other prognostic factors such as tumor stage and grade (16). 
The association between increased NLR and recurrence is complex and remains to be elucidated. Neutrophilia is associated with systemic inflammation and lymphopenia is a marker of immune deficiency. Therefore, proposing NLR as a prognostic marker for RCC patients seems particularly noteworthy. One of the main characteristics of RCC is the response to immunotherapy (17). Cytokines were the main therapy for advanced RCC until the targeted therapy era. The hypotheses for the prognostic role of NLR are immunologic deficiency which may be demonstrated by low lymphocytes and inflammation with neutrophilia. NLR

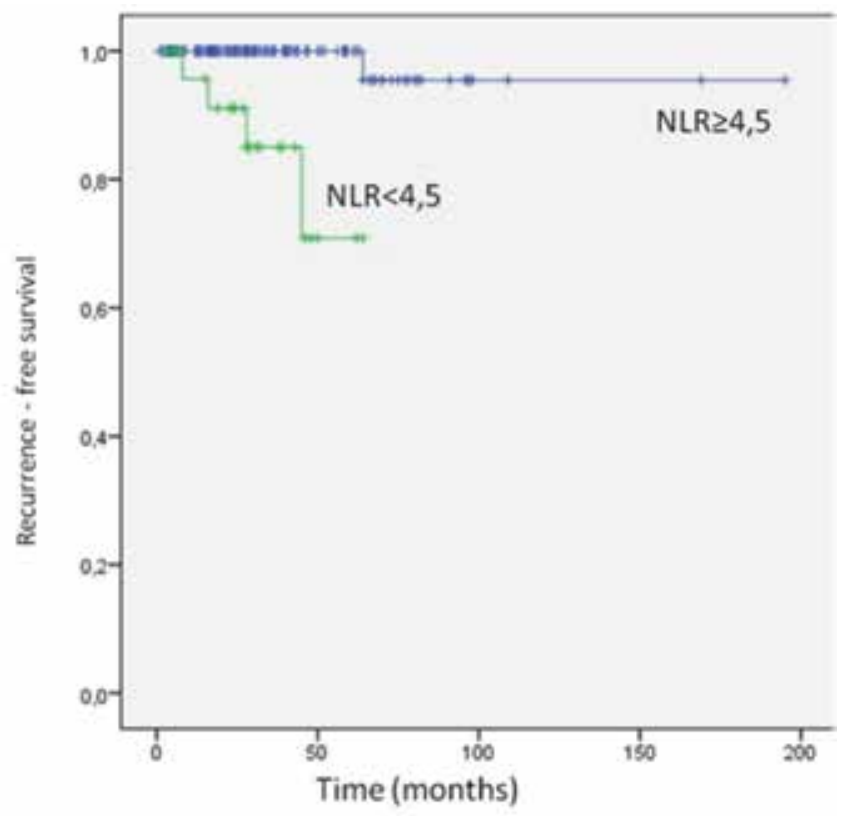

Figure 1. Kaplan-Meier curves of the recurrence free survival rates with regard to neutrophil to lymphocyte ratio (NLR)

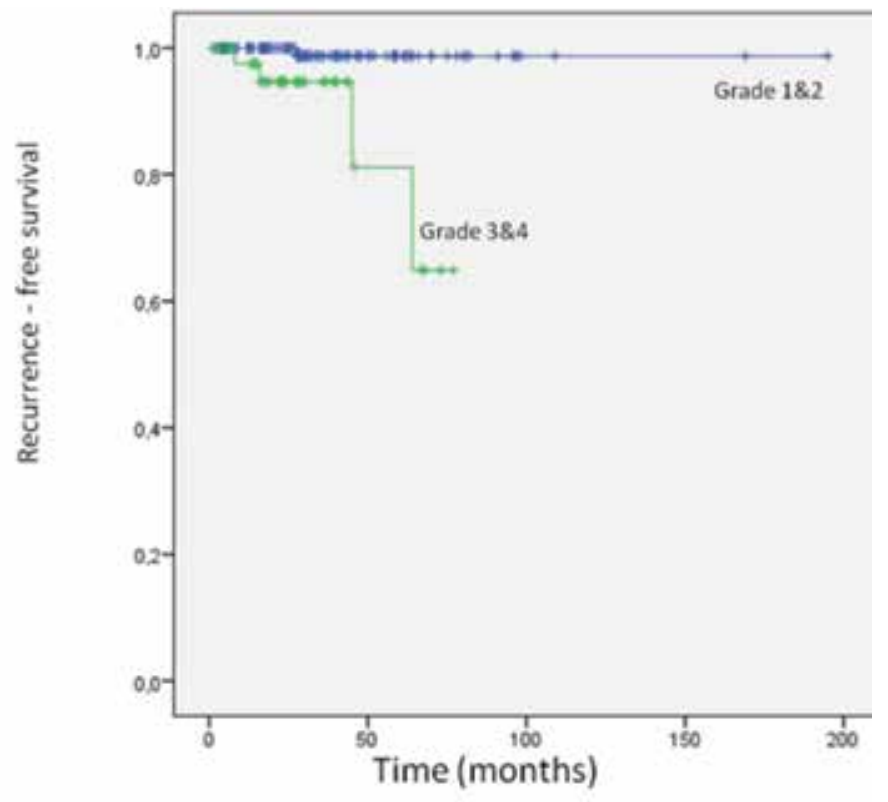

Figure 2. Kaplan-Meier curves of the recurrence free survival rates with regard to Fuhrmann grades for determination of risk of recurrence has been previously studied by Ohno et al. (8). In their study, the authors evaluated the role of NLR on development of recurrence. They found that the recurrence free survival rate in patients with a NLR of less than 2.7 was $93.7 \%$ at 5 years and this was significantly higher than the patients with a ratio of 2.7 or greater $77.9 \%$. They also reported that increased preoperative NLR together with the tumor stage was an independent risk factor for the development of recurrence. However, their study population included patients with stage T1-4 and subpopulation of low stage tumors that we are diagnosed more frequently recently were not evaluated separately. Recently de Martino et al. (18) published their data for T1-3N0M0 patients. They have demonstrated $15 \%$ increase for each 1 point of increase in the ratio of NLR. Similar to our study, they found high grade and NLR as an independent prognostic marker. Distinctly, Pichler et al. (19) did not demonstrate NLR as a prognostic marker for over cancer specific or metastasis free survival. Only overall survival was related to high NLR and they commented on a possible role for NLR to predict severe cardiovascular and other comorbidities in these patients.

Our study population consists of only clinical T1a tumors. The cutoff value of NLR was 4.5 for our study, which seems to be higher than previous studies. There were 15 recurrences in our cohort and 12 of these patients had NLR $>4.5$. The main reason for the higher cut-off value may be the excellent prognosis of clinical T1a patients with low recurrence rates, more significant inflammation and immune deficiency to provide a favorable microenvironment for tumor invasion and metastasis. Previous studies mostly included advanced RCC patients and investigated the role of NLR as a biomarker. According to a very recent meta-analysis which included localized and advanced RCC patients, NLR was found as an independent prognostic marker for patients with RCC. They also demonstrated the prognostic role of NLR at localized RCC patients and proposed NLR for prognostic stratification as a biomarker which is simple, robust and convenient (20). The main point of our study was surveillance following surgery for clinical T1a patients. The European Association of Urology Guidelines on Renal Cell Carcinoma recommend a follow-up based on patient's risk factors and type of treatment and gave an infrequent role for imaging modalities for low risk patients (21). We think that in patients with high NLR we should perform an elaborate follow-up.

\begin{tabular}{|l|l|l|l|}
\hline \multicolumn{4}{|l|}{ Table 1. Results of univariate analysis for tumor recurrence } \\
\hline & OR & $95 \% \mathrm{Cl}$ & $\mathbf{p}$ \\
\hline Age & 1.066 & $0.455-1.856$ & 0.844 \\
\hline Gender & 1.147 & $0.792-2.889$ & 0.814 \\
\hline Size & 1.399 & $0.680-3.102$ & 0.428 \\
\hline Fuhrmann Grade $3 \& 4$ & 2.733 & $1.121-5.822$ & $0.001^{*}$ \\
\hline NLR (cut off: 4,50) & 1.934 & $1.078-2.544$ & $0.001^{*}$ \\
\hline Hs-CRP (cut off: $0.655 \mathrm{mg} / \mathrm{L})$ & 1.225 & $0.556-2.487$ & 0.788 \\
\hline Procalcitonin (cut off: $0.078 \mathrm{ng} / \mathrm{mL})$ & 1.266 & $0.603-2.655$ & 0.781 \\
\hline $\begin{array}{l}\text { *Statistically significant } \\
\text { NLR: Neutrophil to lymphocyte ratio, Hs-CRP: High sensitive-C-Reactive protein }\end{array}$
\end{tabular}


The role of CRP was studied previously and conflicting results was demonstrated. Prognostic significance of high CRP levels were shown in some studies $(22,23)$. In the study of Ohno et al. (8) CRP was not shown to be an independent prognostic factor for the development of recurrence. Similarly in our population of T1 RCC patients, hs-CRP measurements were not found to predict development of recurrences. However, there are only 15 patients with developed recurrences in our population and therefore the results should be evaluated with caution. Although CRP is a more accepted biomarker for RCC patients, our outcomes showed NLR as a better biomarker for low stage RCC.

Most important drawback of our study was the retrospective nature and relatively low duration of follow-up. Besides, disease recurrence was observed in only 15 patients, as this is population of low risk for development of recurrence. Therefore the results should be evaluated with caution and further studies with larger population longer duration of follow up is needed. In conclusion, preoperative elevation of measurement of NLR has been found to be associated with increased risk of recurrence in stage pathological T1a RCC patients. As a widely available biomarker the clinicians may utilize NLR to adjust their management for low risk RCC. Studies with longer duration of follow up, prospective and larger populations are needed.

\section{Ethics}

Ethics Committee Approval: Retrospective study, Informed. Consent: Retrospective study.

Peer-review: Internal peer-reviewed.

\section{Authorship Contributions}

Surgical and Medical Practices: Semih Tangal, Evren Süer, Concept: Sümer Baltacl, Design: Evren Süer, Data Collection or Processing: Barış Esen, Analysis or Interpretation: Mehmet Illker Gökçe, Nurullah Hamidi, Literature Search: Nurullah Hamidi, Writing: Mehmet Illker Gökçe.

Conflict of Interest: No conflict of interest was declared by the authors.

Financial Disclosure: The authors declared that this study received no financial support.

\section{References}

1. Lindblad P. Epidemiology of renal cell carcinoma. Scand J Surg 2004;93:88-96.

2. Tsui KH, Shvarts O, Smith RB, et al. Renal cell carcinoma: Prognostic significance of incidentally detected tumors. J Urol 2000;16:426-430.

3. Shuch BM, Lam JS, Belldegrun AS, Figlin RA. Prognostic factors in renal cell carcinoma. Semin Oncol 2006;33:563-575.

4. Walsh SR, Cook EJ, Goulder F, et al. Neutrophil-lymphocyte ratio as a prognostic factor in colorectal cancer. J Surg Oncol 2005;91:181-184.
5. Ubukata H, Motohashi G, Tabuchi T, et al. Evaluations of interferon- $\gamma /$ interleukin-4 ratio and neutrophil/lymphocyte ratio as prognostic indicators in gastric cancer patients. J Surg Oncol 2010;102:742-747.

6. Cho H, Hur HW, Kim SW, et al. Pre-treatment neutrophil to lymphocyte ratio is elevated in epithelial ovarian cancer and predicts survival after treatment. Cancer Immunol Immunother 2009;58:15-23.

7. Kao SC, Pavlakis N, Harvie R, et al. High blood neutrophil-tolymphocyte ratio is an indicator of poor prognosis in malignant mesothelioma patients undergoing systemic therapy. Clin Cancer Res 2010;16:5805-5813.

8. Ohno $Y$, Nakashima J, Ohori M, et al. Pretreatment neutrophil-tolymphocyte ratio as an independent predictor of recurrence in patients with non metastatic renal cell carcinoma. J Urol 2010;184:873-878.

9. Ohno $Y$, Nakashima J, Ohori $M$, et al. Follow up of neutrophil-tolymphocyte ratio and recurrence of clear cell renal cell carcinoma. I Urol 2012;187:411-417.

10. Komai Y, Saito K, Sakai K, Morimoto S. Increased preoperative serum C-reactive protein level predicts a poor prognosis in patients with localized renal cell carcinoma. BJU Int 2007;99:77-80.

11. Ito K, Asano T, Yoshii $\mathrm{H}$, et al. Impact of thrombocytosis and C-reactive protein elevation on the prognosis for patients with renal cell carcinoma. Int J Urol 2006;13:1365-1370.

12. Giovanella L, Verburg FA, Imperiali $M$, et al. Comparison of serum calcitonin and procalcitonin in detecting medullary thyroid carcinoma among patients with thyroid nodules. Clin Chem Lab Med 2013;51:1477-1481.

13. Walter MA, Meier C, Radimerski T, et al. Procalcitonin levels predict clinical course and progression-free survival in patients with medullary thyroid cancer. Cancer 2010;116:31-40.

14. Fuhrman SA, Lasky LC, Limas C. Prognostic significance of morphologic parameters in renal cell carcinoma. Am J Surg Pathol 1982;6:655-663.

15. Mantovani A, Allavena P, Sica A, Bakwill F. Cancer-related inflammation. Nature 2008;454:436-444.

16. Hamidi N, Gökçe MI, Süer E, Baltaci S. Evaluation of increased preoperative serum high sensitive $\mathrm{C}$-reactive protein and procalcitonin levels on grade and stage of clear cell renal cell carcinoma. Clin Nephrol 2015;83:225-230.

17. Jonasch E, Haluska FG. Interferon in oncological practice: Review of interferon biology, clinical applications, and toxicities. Oncologist 2001;6:34-55.

18. de Martino M, Pantuck Al, Hofbauer S, et al. Prognostic impact of preoperative neutrophil-to-lymphocyte ratio in localized non clear cellrenal cell carcinoma. J Urol 2013;190:1999-2004.

19. Pichler M, Hutterer GC, Stoeckigt C, et al. Validation of the pretreatment neutrophil-lymphocyte ratio as a prognostic factor in a large European cohort of renal cell carcinoma patients. Br J Cancer 2013;108:901-907.

20. Hu K, Lou L, Ye J, Zhang S. Prognostic role of the neutrophil lymphocyte ratio in renal cell carcinoma: A meta-analysis. BMJ Open 2015;5:e006404.

21. Ljungberg $B$, Bensalah $K$, Canfield $S$, et al. EAU guidelines on renal cell carcinoma: 2014 Update. Eur Urol 2015;67:913-924.

22. Casamassima A, Picciariello M, Quaranta $M$, et al. C-reactive protein: A biomarker of survival in patients with metastatic renal cell carcinoma treated with subcutaneous interleukin-2 based immunotherapy. J 